\title{
OPEN The sensitivity of magnetic particle imaging and fluorine-19 magnetic resonance imaging for cell tracking
}

\author{
Olivia C. Sehl ${ }^{1,2 \bowtie} \&$ Paula J. Foster ${ }^{1,2}$
}

Magnetic particle imaging (MPI) and fluorine-19 $\left({ }^{19} \mathrm{~F}\right)$ MRI produce images which allow for quantification of labeled cells. MPI is an emerging instrument for cell tracking, which is expected to have superior sensitivity compared to ${ }^{19} \mathrm{~F}$ MRI. Our objective is to assess the cellular sensitivity of MPI and ${ }^{19} \mathrm{~F}$ MRI for detection of mesenchymal stem cells (MSC) and breast cancer cells. Cells were labeled with ferucarbotran or perfluoropolyether, for imaging on a preclinical MPI system or 3 Tesla clinical MRI, respectively. Using the same imaging time, as few as $4000 \mathrm{MSC}$ ( $76 \mathrm{ng}$ iron) and 8000 breast cancer cells $\left(74 \mathrm{ng}\right.$ iron) were reliably detected with $\mathrm{MPI}$, and $256,000 \mathrm{MSC}\left(9.01 \times 10^{16}{ }^{19} \mathrm{~F}\right.$ atoms) were detected with ${ }^{19} \mathrm{~F}$ MRI, with SNR $>5$. MPI has the potential to be more sensitive than ${ }^{19} \mathrm{~F} \mathrm{MRI}$ for cell tracking. In vivo sensitivity with MPI and ${ }^{19} \mathrm{~F}$ MRI was evaluated by imaging MSC that were administered by different routes. In vivo imaging revealed reduced sensitivity compared to ex vivo cell pellets of the same cell number. We attribute reduced MPI and ${ }^{19} \mathrm{~F}$ MRI cell detection in vivo to the effect of cell dispersion among other factors, which are described.

Cellular imaging with magnetic particle imaging (MPI) and magnetic resonance imaging (MRI) enables the tracking of cellular therapies and the fate of cancer cells. MPI and Fluorine-19 $\left({ }^{19} \mathrm{~F}\right) \mathrm{MRI}$ are advantageous as they provide positive image contrast with quantifiable signal, without the use of ionizing radiation. This allows for specific and longitudinal tracking of cells and linear cell quantification. MRI has been used to image therapeutic cells in patients ${ }^{1}$, whereas MPI is an emerging modality for cell tracking and currently limited to preclinical studies. In this study, we evaluate the sensitivity of preclinical MPI and ${ }^{19} \mathrm{~F}$ MRI on a clinical system for imaging of two cell types: mesenchymal stem cells (MSC) and breast cancer cells.

Therapeutic MSC have great potential for regenerative medicine. There are over 4000 clinical trials ongoing in the U.S, and over 350 in Canada, for stem cell therapies ${ }^{2}$. After administration, many MSC die due to a hostile, pro-inflammatory environment. Importantly, the number of cells that survive and persistence of cells at the implant site provide information on therapeutic status ${ }^{3}$. Critical questions about the safety and success of cell therapies-the delivery, numbers, and persistence of cells-remain unanswered. Cellular imaging has the potential to provide answers, and play a role in optimizing dosage, schedules, and administration routes for cell therapies.

Tracking the fate of cancer cells in preclinical models has been another focus of cellular imaging. Metastasis refers to the spread of cancer from the primary tumor to secondary organs and is the leading cause of death for many types of cancer, including breast cancer. The ability to track the fate of cancer populations provides a powerful tool to study metastasis and potential therapeutics which delay or inhibit metastasis. For cell tracking of MSC and cancer cells, imaging quantification is necessary, and so is the detection of few cells (high cellular sensitivity).

Sensitivity for MPI. MPI directly detects superparamagnetic iron oxide nanoparticles (SPIONs), which are used as cell labeling agents. Strong magnetic gradients $(\mathrm{T} / \mathrm{m})$ are used to localize SPIONs by creating a field-free region (FFR), and oscillating excitation fields (mT) are applied to alter the magnetization of SPIONs present in the FFR. The FFR is traversed across the imaging field of view and the change in SPION magnetization is detected by a receive coil. The resulting image has positive contrast, and the signal is directly related to the amount of SPION and cell number.

The type of SPION and the amount of SPION taken up by cells are two major factors that determine the sensitivity of MPI for cell tracking. Optimal SPIONs for MPI will strongly magnetize with magnetic fields outside the FFR and experience fast relaxation rates within the FFR. Monodisperse, single core SPIONs with core sizes of $\sim 25 \mathrm{~nm}$ have been considered ideal ${ }^{4,5}$. Cell labeling by SPIONs is typically conducted through co-culture and is dependent on endocytosis. Carbohydrate coatings, such as carboxydextran, increase the interactions

${ }^{1}$ Robarts Research Institute, 100 Perth Dr., London, ON N6A 5K8, Canada. ${ }^{2}$ The Department of Medical Biophysics, Western University, 1151 Richmond St., London, ON N6A 3K7, Canada.『email: osehl@uwo.ca 
of SPIONs with cell membranes, similarly, transfection agents can be used to coat SPIONs to enhance their incorporation to cells.

The most commonly used SPION for MPI is ferucarbotran (VivoTrax ${ }^{\mathrm{rm}}$, Magnetic Insight Inc., Alameda, USA), which is repurposed from the original use as an MRI contrast agent (Resovist ${ }^{\oplus}$, Bayers Healthcare). Ferucarbotran has a carboxydextran coat and is a polydisperse agent; some nanoparticles have a core size of $24 \mathrm{~nm}$ $(30 \%)$ and the majority have $5 \mathrm{~nm}$ cores $^{6}$. The in vitro detection limit using ferucarbotran has been estimated to be approximately 1000 embryonic stem cells $(27 \mathrm{pg} / \text { cell })^{7}$. SPIONs designed specifically for MPI are being investigated and show improved performance; in vivo, Wang et al. (2020) demonstrated detection of 2500 bone mesenchymal stem cells with cubic nanoparticles $(29 \mathrm{pg} / \mathrm{cell})^{8}$. Beyond this, detection limits for SPION-labeled cells have not been carefully studied.

Sensitivity for ${ }^{19} \mathrm{~F}$ MRI. For ${ }^{19} \mathrm{~F}$ MRI, cells can be labeled with perfluorocarbon agents such as perfluoropolyether (PFPE) nanoemulsions. Since there is little endogenous ${ }^{19} \mathrm{~F}$ in biological tissues, these cells can be visualized with high specificity. The signal intensity of these images is directly linear to the number of ${ }^{19} \mathrm{~F}$ atoms and cell number. The sensitivity of ${ }^{19} \mathrm{~F}$ MRI cell tracking is impacted by ${ }^{19} \mathrm{~F}$ cellular loading. PFPE are formulated into nanoemulsions for safe and effective labeling of cells; clinical-grade PFPE agents are available (CS-1000, CelSense Inc.) and have been used in humans ${ }^{9}$. The amount of ${ }^{19} \mathrm{~F}$ uptake is different for various cell types due to differences in cell size and endocytic ability ${ }^{10}$.

MRI hardware and imaging parameters also play a major role in determining ${ }^{19} \mathrm{~F}$ sensitivity. Higher magnetic field strengths improve detectability of cells, additionally, the use of specialized coils is integral. For example, our group has previously demonstrated comparable signal detection at $9.4 \mathrm{~T}$ using a birdcage coil compared to $3 \mathrm{~T}$ using a surface coill ${ }^{11}$.

${ }^{19} \mathrm{~F}$ cellular detection limits using various field strengths, hardware, and sequences have been reviewed by Srinivas et al. ${ }^{10}$. Notably, there were no reported studies at field strengths $\leq 3 \mathrm{~T}$. The translation of cellular MRI techniques to the clinic will require the use of human MRI systems at clinical field strengths. Our group has demonstrated a cellular detection limit of 25,000 PFPE-labeled macrophages in vitro at $3 \mathrm{~T}^{11}$. In the first human clinical trial at $3 \mathrm{~T}$, an in vivo cellular detection limit between 1 and 10 million dendritic cells was demonstrated ${ }^{9}$. The sensitivity of ${ }^{19} \mathrm{~F}$ MRI for detection of MSC and breast cancer cells at $3 \mathrm{~T}$ has not been evaluated.

MPI and ${ }^{19} \mathrm{~F}$ MRI have similar characteristics for cell tracking (positive contrast and quantitation), and MPI is expected to be more sensitive for cell tracking, however, this has not been carefully compared. The objective of this study is to assess the in vitro and in vivo cellular sensitivity of MPI and ${ }^{19} \mathrm{~F} \mathrm{MRI} \mathrm{for} \mathrm{MSC} \mathrm{and} \mathrm{breast}$ cancer cells.

\section{Methods}

Cell culture. $\quad 4 \mathrm{~T} 1$ murine breast cancer cells (Dr. Fred Miller, Wayne State University, MI, USA) were maintained in Dulbecco's modified Eagle's medium (DMEM) (Gibco, Thermo Fisher Scientific, MA, USA) with 10\% fetal bovine serum (FBS) and antimycotic/antibiotic. MSCs derived from the bone marrow of C57BL/6 mice (MUBMX- 01101 [BE], Cedarlane, Burlington, Ontario, Canada) were cultured in low-glucose DMEM (Thermo Fisher Scientific) with $10 \%$ FBS. Cells were maintained at $37^{\circ} \mathrm{C}$ and $5 \% \mathrm{CO}_{2}$ and passaged every $2-3$ days for 10 days.

Cell labeling. $\quad 2 \times 10^{6} 4 \mathrm{~T} 1 \mathrm{cells}$ or MSCs were seeded for labeling in T75 $\mathrm{cm}^{2}$ flasks. After $24 \mathrm{~h}, 2.5 \mathrm{mg} / \mathrm{mL}$ PFPE nanoemulsion (Cell Sense, Celsense Inc., Pittsburgh, PA, USA) was added to $10 \mathrm{~mL}$ complete media and left to co-incubate overnight ${ }^{12,13}$. Alternatively, cells were labeled with $55 \mu \mathrm{g} \mathrm{Fe} / \mathrm{mL}$ ferucarbotran (Vivotrax, Magnetic Insight Inc., Alameda, CA, USA) using transfection agents in a protocol described by Thu et al. ${ }^{14}$ Briefly, $60 \mu \mathrm{L}$ protamine sulfate (stock $10 \mathrm{mg} / \mathrm{mL}$ ) was added to $2.5 \mathrm{~mL}$ of serum-free medium, and in a second tube, $20 \mu \mathrm{L}$ heparin (stock $1000 \mathrm{U} / \mathrm{mL}$ ) and $90 \mu \mathrm{L}$ ferucarbotran (stock $5.5 \mathrm{mg} / \mathrm{mL}$ ) was added to $2.5 \mathrm{~mL}$ serumfree medium. These two tubes were individually vortexed, then combined. After adhered 4T1 cells or MSC were washed in PBS, this labeling mix was added to the cells. $4 \mathrm{~h}$ later, $5 \mathrm{~mL}$ of complete media was added to cells and left to co-incubate overnight.

Evaluation of cell labeling. A cytospin of $100 \times 10^{3}$ cells was prepared for all labeled cells which were fixed in 3:1 methanol:acetic acid. Iron-labeled cells were stained with Perl's Prussian blue (PPB) to identify iron in cells ${ }^{15} .{ }^{19} \mathrm{~F}$-labeled cells were labeled with nuclear fast red to assess for PFPE nanodroplets ${ }^{11}$. Microscopy of these slides was conducted using the EVOS imaging system (M7000, Thermo Fischer Scientific). The mean intracellular ${ }^{19} \mathrm{~F}$ content in MSC was measured by NMR using a Varian Inova 400 spectrometer (Varian Inc, Paulo Alto, USA) and methods previously described ${ }^{11}$.

Preparation of cell pellets for imaging. PFPE-labeled cells or ferucarbotran-labeled cells were washed 3 times in phosphate-buffered saline (PBS) and collected in triplicate samples prepared in a dilution series: 1024, $512,256,128,64,32,16,8,4,2,1,0.5\left(\times 10^{3}\right)$ cells. Ferucarbotran-labeled cells were pelleted in $50 \mu \mathrm{L}$ PBS for MPI. ${ }^{19} \mathrm{~F}$-labeled cells were pelleted by centrifugation and covered in $50 \mu \mathrm{L}$ agarose. This process was repeated two more times to produce a total of 9 replicates for each cell number and cell type (4T1 or MSC), with each cell labeling agent (PFPE or ferucarbotran).

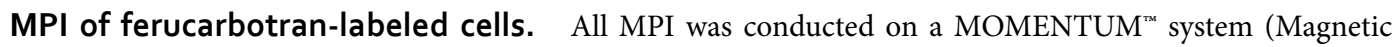
Insight Inc.) (Fig. 1A). A small well was secured to the imaging bed where a PCR tube containing the cell 
A
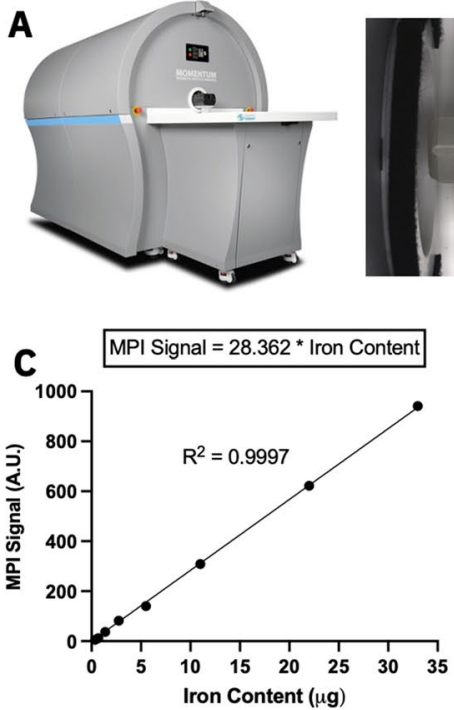

B

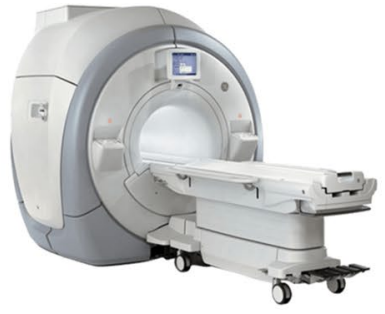

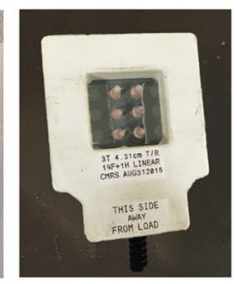
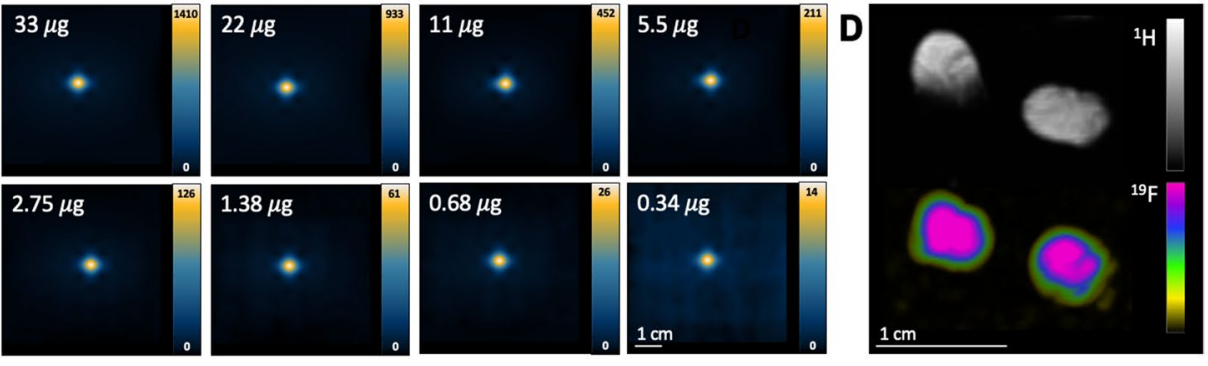

Figure 1. (A) Image of a preclinical Momentum MPI and sample holder (white arrow), where individual ferucarbotran-labeled cell samples were placed for imaging. (B) Photos of a clinical 3 Tesla MRI with the dualtuned $\left({ }^{1} \mathrm{H} /{ }^{19} \mathrm{~F}\right)$ surface coil, used for ${ }^{19} \mathrm{~F}$ imaging of 6 cell samples. (C) A strong linear relationship exists between MPI signal and iron mass $\left(\mathrm{R}^{2}=0.9997\right)$. This was determined by imaging multiple samples of ferucarbotran $(0.34-33 \mu \mathrm{g})$ and measuring the MPI signal from each sample. The linear equation is subsequently used to convert a measure of MPI signal from ferucarbotran-labeled cells to a measure iron content $(\mu \mathrm{g})$. (D) ${ }^{1} \mathrm{H}$ and ${ }^{19} \mathrm{~F}$ images of two reference phantoms, containing known amount of ${ }^{19} \mathrm{~F}$ content $\left(3.33 \times 10^{16}{ }^{19} \mathrm{~F} \mathrm{spins} / \mu \mathrm{L}\right)$, are used for quantification of ${ }^{19} \mathrm{~F}$ in cell samples.

pellet could be placed. This allowed for imaging to occur in the identical location and for the user to easily transfer cell samples. Each cell pellet was imaged individually with the following parameters: field of view $(\mathrm{FOV})=6 \mathrm{~cm} \times 6 \mathrm{~cm}$, gradient strength $=3.0 \mathrm{~T} / \mathrm{m}$, dual-channel acquisition (X and Z), excitation amplitude $=22$ $\mathrm{mT}(\mathrm{X}$-channel) and $26 \mathrm{mT}$ (Z-channel), imaging time $=1.5 \mathrm{~min}$. Cell pellets were imaged in descending order of cell number. Once the cell pellet was undetected, 2D imaging with 8 averages (imaging time $=11.8 \mathrm{~min}$ ) and $3 \mathrm{D}$ imaging was conducted for all 9 replicates, in attempt to improve MPI sensitivity. 3D images combine 35 projections in a FOV $=6 \times 6 \times 6 \mathrm{~cm}$ (imaging time $=22.8 \mathrm{~min}$ ). If cells were detected in these longer scans, fewer cells were imaged until undetected in 2D (8 averages) and 3D.

${ }^{19} \mathrm{~F}$ MRI of perfluorocarbon-labeled cells. ${ }^{19} \mathrm{~F}$ images were acquired on a clinical $3 \mathrm{~T}$ MRI (Discovery MR750, General Electric) using a $4.31 \times 4.31 \mathrm{~cm}$ diameter dual tuned $\left({ }^{1} \mathrm{H} /{ }^{19} \mathrm{~F}\right)$ surface coil (Clinical MR Solutions, Wisconsin) (Fig. 1B). Six samples of 32, 64, 128, 256, 512, $1024\left(\times 10^{3}\right)$ cells (from the same replicate) were imaged at a time using a $3 \mathrm{D}$ balanced steady state free precession (bSSFP) pulse sequence. ${ }^{19} \mathrm{~F}$ imaging parameters were: $\mathrm{FOV}=40 \times 20 \mathrm{~mm}$, matrix $=40 \times 20$, slice thickness $=1 \mathrm{~mm}\left(1 \times 1 \times 1 \mathrm{~mm}^{3}\right.$ resolution $)$, repetition time/echo time $=5.6 \mathrm{~ms} / 2.8 \mathrm{~ms}$, bandwidth $= \pm 10 \mathrm{kHz}$, and flip angle $=72^{\circ}$. Flip angle was optimized through a series of ${ }^{19} \mathrm{~F}$ images (Fig. S1) and calculated using reported $\mathrm{T} 1$ and $\mathrm{T} 2$ times at $3 \mathrm{~T}^{9,16}$. Cell pellets were imaged with 115 excitations (imaging time of $9.5 \mathrm{~min}$, or $1.5 \mathrm{~min} /$ pellet) and 345 excitations (imaging time of $28.3 \mathrm{~min}$, or $4.5 \mathrm{~min} /$ pellet).

In vivo detection of MSC using MPI and ${ }^{19} \mathrm{~F}$ MRI. Seven NOD/SCID/ILIIrg-/-(NSG) mice were obtained and cared for in accordance with the standards of the Canadian Council on Animal Care. The study was approved by the Animal Use Subcommittee of Western University's Council on Animal Care. All methods were carried out in accordance with relevant guidelines and regulations. This study was carried out in compliance with the ARRIVE guidelines.

In preparation for MPI, 4 mice were fasted for $12 \mathrm{~h}$, by removing food pellets from their cages, and a piece of ex-lax (regular strength stimulant laxative) was added to the cage. Additionally, cotton bedding, which has been shown to produce MPI signal (unpublished results) was replaced with corn bedding. The goal of these measures was to minimize background signal associated with the iron in the mouse digestive system.

To investigate differences in sensitivity in vivo, $1 \times 10^{5}$ ferucarbotran-labeled MSC were injected to NSG mice by subcutaneous, intraperitoneal, or intravenous injection. A fourth mouse received $2 \times 10^{6}$ ferucarbotran-labeled MSC by subcutaneous injection. Each mouse was imaged with MPI with a FOV $=12 \mathrm{~cm} \times 6 \mathrm{~cm} \times 6 \mathrm{~cm}$ in $2 \mathrm{D}$ $(2.2 \mathrm{~min})$. All other imaging parameters are described above. MPI was conducted immediately before injections, to measure background signal, and immediately after injections. MPI signal for each mouse was calculated as the difference between pre-injection signal (background) and post-injection signal. MPI signal from cells in vivo was compared to MPI signal from cell pellets.

Similarly, $2 \times 10^{6}$ PFPE-labeled MSC were injected to NSG mice by subcutaneous or intraperitoneal injection. A third mouse received fewer PFPE-labeled cells $\left(1 \times 10^{5}\right)$ by subcutaneous administration. Following cell 
administration, ${ }^{19} \mathrm{~F}$ MRI was conducted for each mouse by placing the surface coil directly above the injection site to maximize sensitivity (shown in Fig. 7E); the mouse receiving cells by subcutaneous was prone for imaging and the mouse receiving cells by intraperitoneal injection was supine. Imaging parameters are the same as listed above, however with a FOV $=60 \times 30 \mathrm{~mm}$ with matrix size $=60 \times 30\left(1 \times 1 \times 1 \mathrm{~mm}^{3}\right.$ resolution $)$, and 200 excitations (imaging time $=35.5 \mathrm{~min}$ ). In vivo ${ }^{19} \mathrm{~F}$ signal was quantified (described below) and compared to signal detected from cell pellets, which were included alongside the mouse.

Image analysis. For MPI signal calibration, an additional 8 samples of ferucarbotran $(5.5 \mathrm{mg} / \mathrm{mL})$ were imaged with identical parameters in a dilution series in PBS: $33,22,11,5.5,2.25,1.38,0.68,0.34 \mu \mathrm{g}$ ferucarbotran. A linear relationship was found between iron mass and MPI signal (Fig. 1C) and the equation of the line was used to calculate associated iron content from each cell sample.

2D MPI of the empty sample holder was conducted at the beginning $(0 \mathrm{~h})$, middle $(3 \mathrm{~h})$, and end $(6 \mathrm{~h})$ of six imaging sessions. The standard deviation of background noise $\left(\mathrm{SD}_{\text {noise }}\right)$ was measured in these 18 images. To quantify signal from ferucarbotran-labeled cells in pellets and in vivo, a threshold of 5 times the average background $\mathrm{SD}_{\text {noise }}$ was used to mask lower amplitude signal and yield a reliable measurement of MPI signal. This imaging criteria is based on MPI signal with SNR $>5$ (Rose Criterion) ${ }^{17}$. Total MPI signal was calculated as mean MPI signal ${ }^{\star}$ volume of ROI $\left(\mathrm{mm}^{2}\right.$ or $\left.\mathrm{mm}^{3}\right)$.

Delineation of ${ }^{19} \mathrm{~F}$ signal was conducted using a similar method as MPI $\left(5^{\star} \mathrm{SD}_{\text {noise }}\right)$. Background $\mathrm{SD}_{\text {noise }}$ of ${ }^{19} \mathrm{~F}$ signal for each 3D image was measured by drawing an ROI in background noise of one image slice. Due to Rician distribution observed in background signal noise, ${ }^{19} \mathrm{~F}$ signal between $5^{\star} \mathrm{SD}_{\text {noise }}$ and $8^{\star} \mathrm{SD}_{\text {noise }}$ was corrected using a factor of 0.655 , as described by Bouchlaka et al. (2016) ${ }^{18}$ (Fig. S2). Total ${ }^{19} \mathrm{~F}$ signal was calculated as mean ${ }^{19} \mathrm{~F}$ signal * volume of ROI. Two reference phantoms containing $3.33 \times 10^{16}{ }^{19} \mathrm{~F}$ spins $/ \mu \mathrm{L}$ were included in the imaging field of view for calibration (Fig. 1D). ${ }^{19} \mathrm{~F}$ content from cell pellets was calculated as:

$$
19 F \text { spins in } R O I=(\text { signal in } R O I) *\left(3.33 \times 10^{16} \frac{19 F \text { spins }}{\mu L}\right) *\left(\frac{\text { volume of phantoms in } \mathrm{mm}^{3}}{\text { average signal in phantoms }}\right)
$$

We defined MPI and ${ }^{19} \mathrm{~F}$ MRI in vitro cell detection limits as the minimum number of MSC and $4 \mathrm{~T} 1$ cells detected with SNR $>5$. Thus, cells with signal below the $5^{\star} \mathrm{SD}_{\text {noise }}$ criteria were considered undetected. The amount of ferucarbotran or PFPE associated with the lowest cell number was calculated as iron mass per cell * number of cells or ${ }^{19} \mathrm{~F}$ atoms per cell ${ }^{\star}$ number of cells, respectively.

Statistical analysis. All statistical analysis were performed using GraphPad Prism version 9. Linear regression was performed for MPI calibration (known iron mass vs. measured MPI signal) to determine the calibration equation. This line is forced through the origin, under the assumption that background MPI signal, without a sample of iron, has an average of 0 . Pearson's correlation was conducted for MPI (number of cells vs. measured MPI signal) and ${ }^{19} \mathrm{~F}$ MRI (number of cells vs. measured ${ }^{19} \mathrm{~F}$ signal). Analysis of co-variance (ANCOVA) was used to evaluate whether the MPI sensitivity (slope) was significantly different for ferucarbotran-labeled 4T1 cells and MSC (number of cells vs. measured MPI signal). Analysis of variance (ANOVA) was used to analyse differences between MPI signal measured from each cell number and again for ${ }^{19} \mathrm{~F}$ signal measured from each cell number. A p-value of 0.05 was used to determine statistical significance, unless otherwise indicated.

\section{Results}

MPI cellular sensitivity. The detection of ferucarbotran-labeled cells using $2 \mathrm{D}$ MPI (imaging time $=1.5 \mathrm{~min}$ ) is shown in Fig. 2A (4T1 cells) and Fig. 3A (MSC). MPI signal measured from samples of 8000-1,024,000 4T1 cells and 4000-1,024,000 MSC had SNR > 5. The iron mass significantly increased with cell number for both cell types (Figs. 2A, 3A). Importantly, the standard deviation of background noise, measured three times over six imaging sessions, showed no significant differences (Fig. S3).

MPI signal (and the associated iron content) was strongly correlated with cell number for ferucarbotranlabeled 4T1 cells and MSC (Fig. 5A). The slope of the line was significantly steeper (factor of 2.07) for MSC compared to $4 \mathrm{~T} 1$ cells $(P<0.0001)$. Enhanced ferucarbotran labeling was measured in MSC $(19.09 \pm 2.50 \mathrm{pg}$ $\mathrm{Fe} /$ cell) compared to $4 \mathrm{~T} 1$ cells $(9.22 \pm 1.42 \mathrm{pg}$ Fe/cell), which can be visualized in PPB-stained cells (Fig. 5B).

With 2D MPI, the lowest cell numbers detected with SNR $>5$ were $80004 \mathrm{~T} 1$ cells (6/9 replicates, corresponding to $74 \mathrm{ng}$ iron) and $4000 \mathrm{MSC}$ (8/9 replicates, corresponding to $76 \mathrm{ng}$ iron). All other replicates of $80004 \mathrm{~T} 1$ cells and $4000 \mathrm{MSC}$ had SNR $>3$. For both cell types, 2D imaging with 8 averages did not improve cell detection (Figs. 2B, 3B). However, additional averaging does reduce the standard deviation of background signal from 0.235 ( 1 average) to 0.183 ( 8 averages $)(P<0.0001)$.

In 3D images $(22.8 \mathrm{~min}$ ), detection of $40004 \mathrm{~T} 1$ cells $(37 \mathrm{ng}$ iron) was enabled ( 3 of 9 replicates $\mathrm{SNR}>5$, and 8 of 9 had SNR $>3$ ) (Fig. 2C). Improvements to detection of MSC was also seen in 3D; 2000 MSC (38 ng iron) were detected ( 6 of 9 replicates SNR $>5$, and 9 of 9 had SNR $>3$ ) (Fig. 3C). In 4 of 9 replicates, the detection of 1000 MSC (19 ng iron) was possible in 3D with a threshold of $\mathrm{SNR}>3$.

${ }^{19} \mathrm{~F}$ MRI Cellular Sensitivity. MSC were labeled with $3.52 \pm 1.55 \times 10^{11}{ }^{19} \mathrm{~F} / \mathrm{cell}(\mathrm{NMR})$ and the nanodroplets associated with the ${ }^{19} \mathrm{~F}$ agent were identified with microscopy (Fig. 5D). The average number of ${ }^{19} \mathrm{~F}$ spins determined by NMR was not significantly different from that measured by MRI in both short $(P=0.3648)$ and long scans $(P=0.8541)$. $4 \mathrm{~T} 1$ cells did not label sufficiently with PFPE, as ${ }^{19} \mathrm{~F}$ content in $1 \times 10^{6}$ cells was undetected by NMR. Thus, ${ }^{19} \mathrm{~F}$ imaging experiments with PFPE-labeled $4 \mathrm{~T} 1$ cells did not continue. 


\section{A 2D, 1 average}
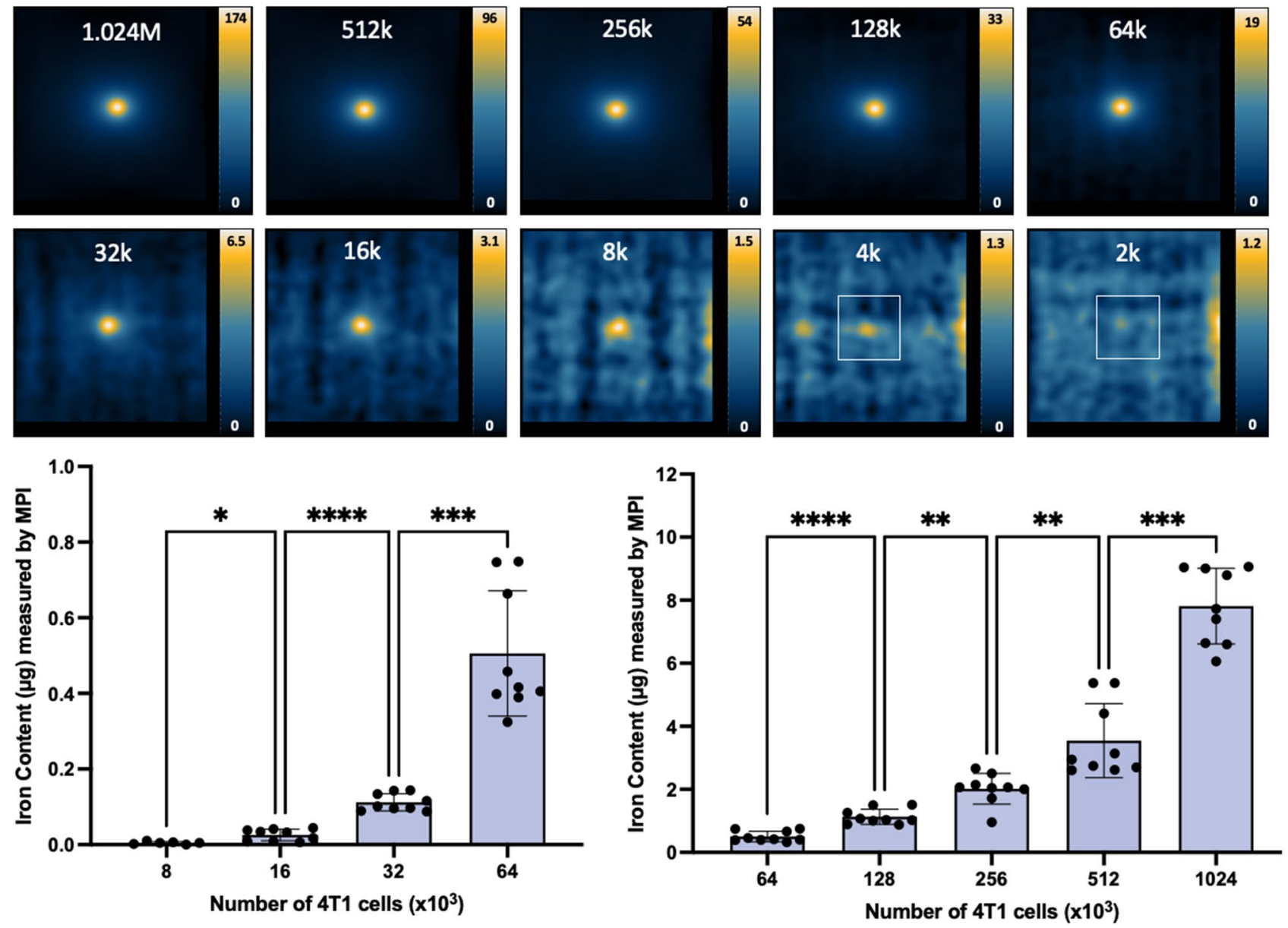

B 2D, 8 averages
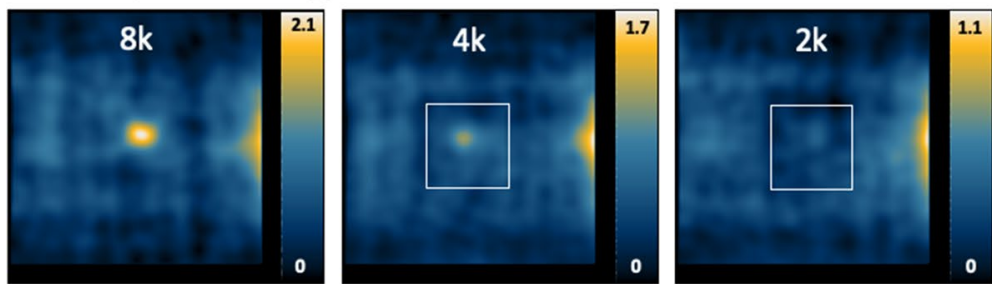

C 3D, 35 projections
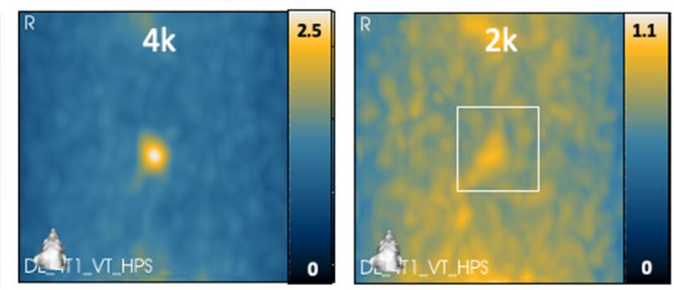

Figure 2. MPI detection of ferucarbotran-labeled 4T1 cells. (A) 2D MPI of individual $4 \mathrm{~T} 1$ cell pellets containing the indicated cell numbers $\left(\mathrm{M}=10^{6}, \mathrm{k}=10^{3}\right)$. As few as 8000 cells $(0.074 \mu \mathrm{g}$ ferucarbotran $)$ could be detected with SNR $>5$ in $1.5 \mathrm{~min}$. 2D MPI signal (and the associated iron content) significantly increases with the number of 4 T1 cells $\left({ }^{\star} P<.05,{ }^{* *} P<.01,{ }^{* *} P<.001,{ }^{* * * *} P<.0001\right)$. (B) With 8 signal averages, the same result was found. (C) In 3D, the detection of 4000 cells $(0.037 \mu \mathrm{g}$ ferucarbotran) with SNR $>5$ was possible in $23 \mathrm{~min}$. Images with $\mathrm{SNR}<5$ have white boxes to indicate the placement of the cell sample.

In ${ }^{19} \mathrm{~F}$ images (with imaging time $=1.5 \mathrm{~min} /$ pellet), the range of $256-1024 \times 10^{3} \mathrm{PFPE}-$ labeled MSC were detected (Fig. 4A) and ${ }^{19} \mathrm{~F}$ signal was strongly correlated with cell number $\left(\mathrm{R}^{2}=0.9983\right)$ (Fig. 5C). The average number of cells detected per voxel from these scans was $1.30 \pm 0.51 \times 10^{5}$ cells $/ \mathrm{mm}^{3}$. The lowest cell number detected from these ${ }^{19} \mathrm{~F}$ scans was $256 \times 10^{3} \mathrm{MSC}\left(9.01 \times 10^{16}{ }^{19} \mathrm{~F}\right.$ atoms, $\left.30.21 \mathrm{mM}\right)$, which was detected in 4 of 9 replicates with $\mathrm{SNR}>5 .{ }^{19} \mathrm{~F}$ signal measured from $1.024 \times 10^{6} \mathrm{MSC}$ was significantly higher than signal measured from $512 \times 10^{3}$ cells $(P<0.01)$, which was higher than signal measured from $256 \times 10^{3}$ cells $(P<0.05)$ (Fig. 4C).

With longer imaging times (4.5 min/pellet), ${ }^{19} \mathrm{~F}$ sensitivity was improved (Fig. $4 \mathrm{~B}$ ) and the $\mathrm{SD}_{\text {noise }}$ was significantly reduced compared to $1.5 \mathrm{~min} /$ pellet scans $(P<0.0001)$. The average number of cells detected per voxel from these scans was $8.55 \pm 2.97 \times 10^{4}$ cells $/ \mathrm{mm}^{3}$. As few as $128 \times 10^{3} \mathrm{MSC}\left(4.51 \times 10^{16}{ }^{19} \mathrm{~F}\right.$ atoms, $\left.19.01 \mathrm{mM}\right)$ were detected with SNR $>5$ in 3 of 9 replicates. Additionally, ${ }^{19} \mathrm{~F}$ signal with SNR $>5$ was detected in 7 of 9 replicates of $256 \times 10^{3} \mathrm{MSC}$, which corresponds to $9.01 \times 10^{16}{ }^{19} \mathrm{~F}$ atoms $(28.01 \mathrm{mM})$. Significant differences in ${ }^{19} \mathrm{~F}$ signal 


\section{A 2D, 1 average}
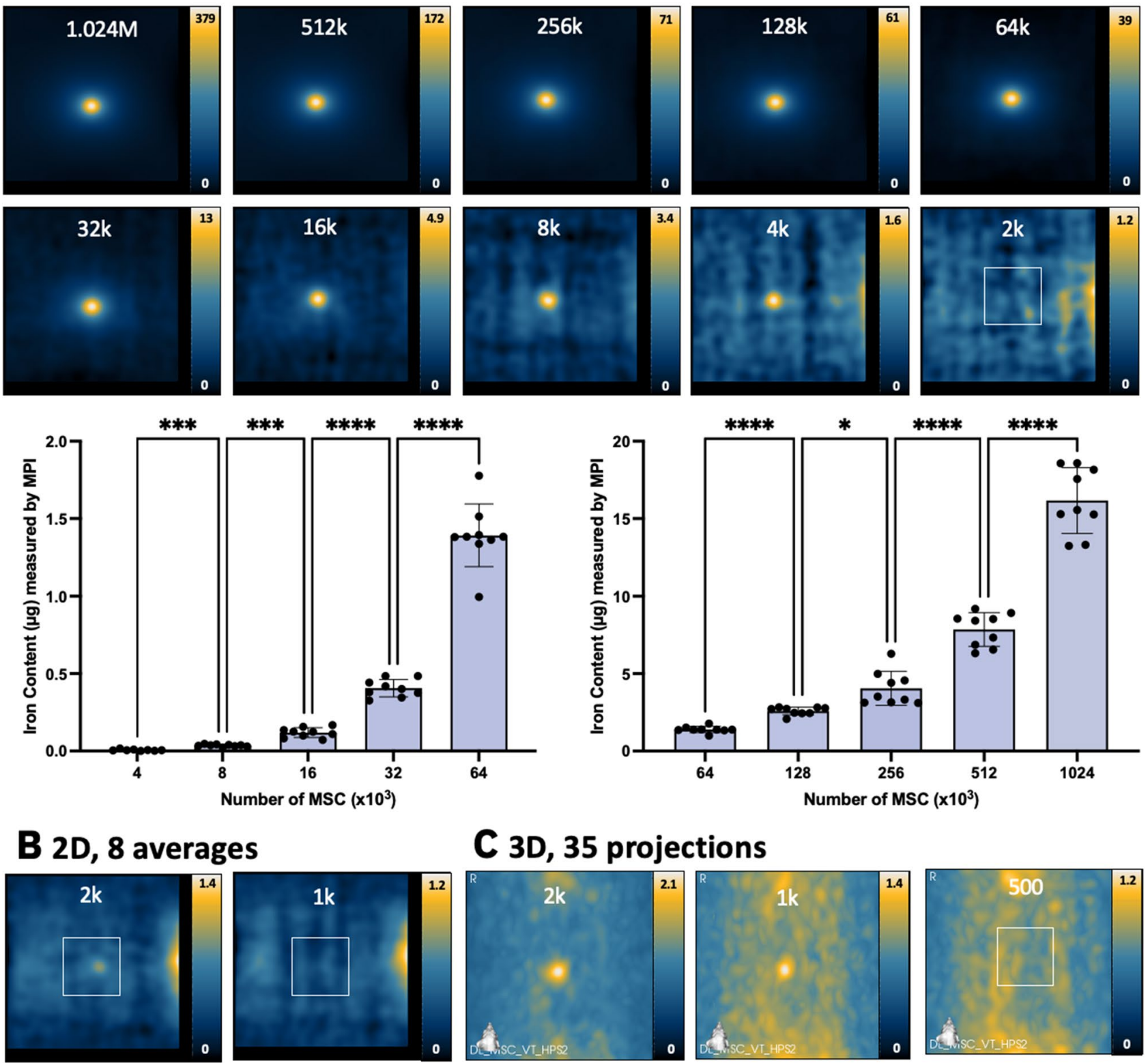

\section{B 2D, 8 averages}
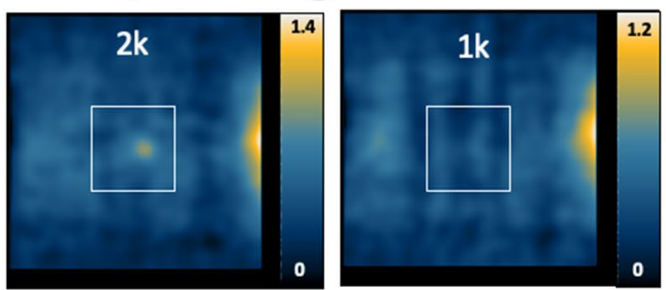

C 3D, 35 projections

Figure 3. MPI detection of ferucarbotran-labeled MSC. (A) 2D MPI of individual MSC pellets containing the indicated cell numbers $\left(\mathrm{M}=10^{6}, \mathrm{k}=10^{3}\right)$. As few as $4000 \mathrm{MSC}(0.076 \mu \mathrm{g}$ ferucarbotran $)$ could be detected with SNR $>5$ in $1.5 \mathrm{~min}$. 2D MPI signal (and the associated iron content) significantly increases with the number of MSC $\left({ }^{\star} P<.05,{ }^{* *} P<.01,{ }^{* *} P<.001,{ }^{* * *} P<.0001\right)$. (B) With 8 signal averages, the same result was found. (C) In $3 \mathrm{D}$, the detection of 2000 cells $(0.038 \mu \mathrm{g}$ ferucarbotran, with SNR $>5)$ and 1000 cells $(0.019 \mu \mathrm{g}$ ferucarbotran, with $\mathrm{SNR}>3$ ) was possible in $23 \mathrm{~min}$. Images with $\mathrm{SNR}<5$ have white boxes to indicate the placement of the cell sample.

were measured from 256, 512, and $1024\left(\times 10^{3}\right)$ MSC (Fig. 4C). Furthermore, significantly more ${ }^{19} \mathrm{~F}$ signal was measured from $1.024 \times 10^{6}$ cells when using longer imaging times (4.5 min/pellet) compared to $1.5 \mathrm{~min} /$ pellet $(P<0.01)$.

In vivo sensitivity of MPI and ${ }^{19} \mathrm{~F}$ MRI. A comparison between MPI signal from a cell pellet and cells in vivo was conducted with different injection routes (Fig. 6A). These MSC were labeled with $28.9 \pm 3.4 \mathrm{pg}$ iron/ cell. Compared to a pellet of $2 \times 10^{6}$ ferucarbotran-labeled MSC, MPI signal was only reduced by $5 \%$ with subcutaneous injection of these cells (Fig. 6 B,C). Quantification revealed the iron mass measured from the cell pellet $(52.98 \mu \mathrm{g})$ was similar to what was measured after subcutaneous injection $(50.21 \mu \mathrm{g})$. However, for $1 \times 10^{5} \mathrm{MSC}$, in vivo MPI showed a reduction in MPI signal measured from MSC injected subcutaneously (49\%), intraperitoneal (53\%), and intravenous (15\%), compared to signal from a pellet of $1 \times 10^{5}$ MSC (Fig. 6 D,E). For $1 \times 10^{5}$ MSC, the measured iron content was $3.13 \mu \mathrm{g}$ in the cell pellet, compared to $1.52 \mu \mathrm{g}$ after subcutaneous injec- 
A 1.5 minutes/pellet

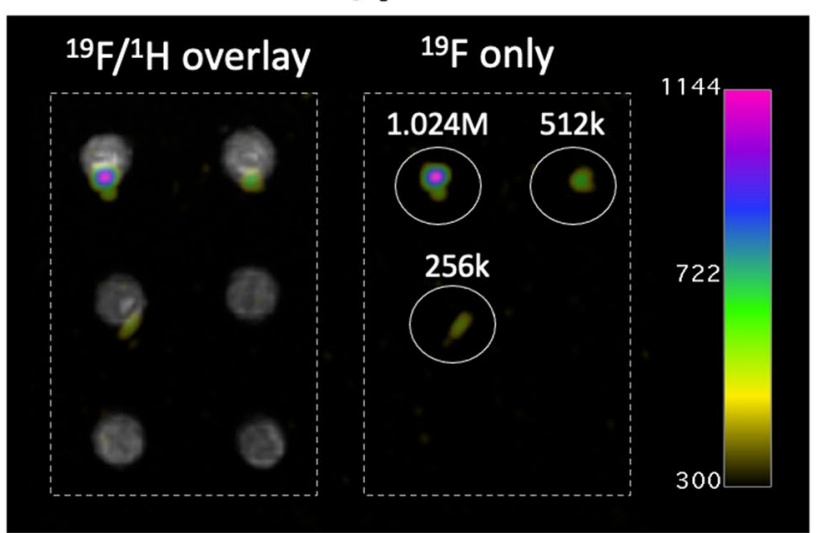

B 4.5 minutes/pellet
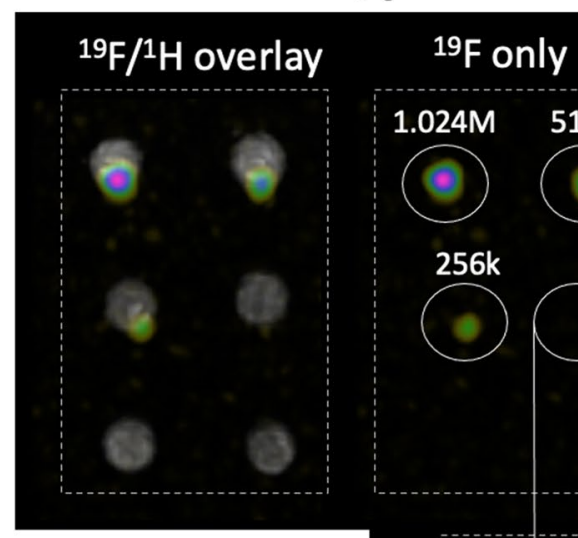

$1.024 \mathrm{M} 512 \mathrm{k}$

\section{7}

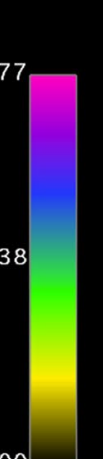

100

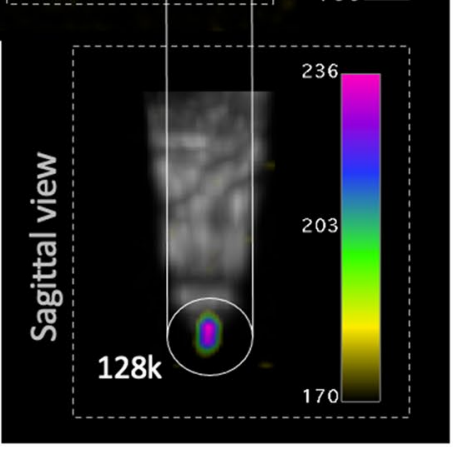

\section{$\square 1.5$ minutes/pellet
4.5 minutes/pellet \\ $\square 1.5$ minutes/pellet
4.5 minutes/pellet}

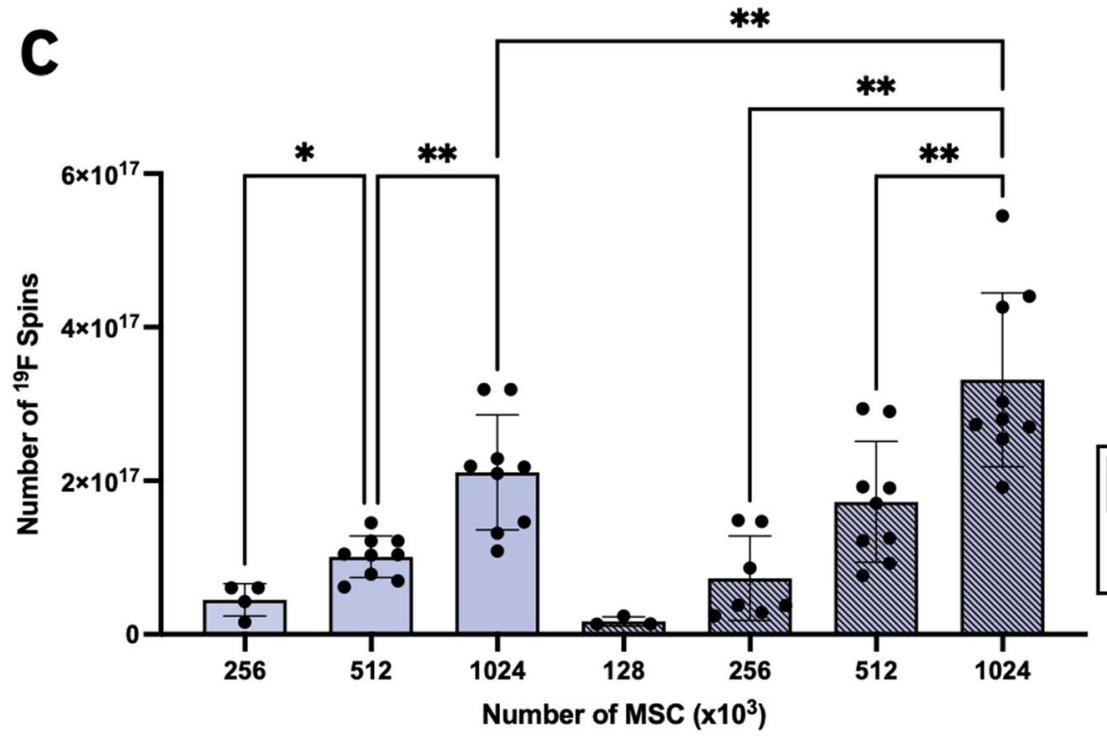

Figure 4. ${ }^{19} \mathrm{~F}$ MRI detection of PFPE-labeled MSC. (A) ${ }^{19} \mathrm{~F}$ images of six samples with various cell numbers $\left(\mathrm{M}=10^{6}, \mathrm{k}=10^{3}\right)$ imaged $1.5 \mathrm{~min} /$ pellet. As few as $256 \times 10^{3}$ cells $\left(9.01 \times 10^{16}{ }^{19} \mathrm{~F}\right.$ atoms $)$ could be detected with $\mathrm{SNR}>5$. (B) With longer imaging time $(4.5 \mathrm{~min} /$ pellet $)$, the detection of $128 \times 10^{3}$ cells $\left(4.51 \times 10^{16}{ }^{19} \mathrm{~F}\right.$ atoms $)$ was possible with $\mathrm{SNR}>5$. (C) Quantification revealed significant differences in ${ }^{19} \mathrm{~F}$ signal between different numbers of MSC $\left({ }^{\star} P<.05,{ }^{*} P<.01\right)$. Significantly more ${ }^{19} \mathrm{~F}$ signal was detected from $1.024 \times 10^{6}$ cell samples with longer imaging times $(P<.01)$.

tion, $1.66 \mu \mathrm{g}$ after intraperitoneal injection, and $0.48 \mu \mathrm{g}$ after intravenous injection. Therefore, the iron content measured from $1 \times 10^{5}$ cells in vivo was reduced compared to cells in the pellet, despite being the same number of cells. After mouse fasting, the background in vivo MPI signal from the mouse digestive system was $25.8 \pm$ 10.0 arbitrary units (A.U.) (shown Fig. 6F). This background signal was accounted for in each mouse by signal subtraction, prior to calculation of MPI signal and iron mass measured from cells.

The detection of $2 \times 10^{6}{ }^{19} \mathrm{~F}$-labeled MSC in vivo was compared to MSC in a pellet (Fig. 7). Reduced ${ }^{19} \mathrm{~F}$ signal (72\%) was detected from MSC following subcutaneous injection (Fig. 7A, D). After intraperitoneal injection, the same number of cells were dispersed and appeared as lower intensity ${ }^{19} \mathrm{~F}$ signal (Fig. 7B), however higher ${ }^{19} \mathrm{~F}$ signal was measured from these cells compared to the pellet by 6.65 times (Fig. 7D). $1 \times 10^{5} \mathrm{MSC}$ administered subcutaneously were undetected as this cell number is below the detection limit (Fig. 7C).

\section{Discussion}

In this study, we began with an evaluation of in vitro sensitivity for MPI and ${ }^{19} \mathrm{~F}$ MRI of cells using ferucarbotran and PFPE nanoemulsions as labeling agents (respectively). Overall, fewer MSC were detected using MPI (4000) compared to ${ }^{19} \mathrm{~F}$ MRI $(256,000)$ using the same imaging time (1.5 min per cell pellet). Compared to ferucarbotran-labeled MSC, more 4T1 cells were required for MPI detection (8000) as a result of lower cell uptake of ferucarbotran. These limits were defined with imaging criteria SNR $>5$ and tested with 9 replicates to provide confidence.

These measurements of lowest cell number detected with MPI and ${ }^{19} \mathrm{~F}$ MRI are reasonable based on previous reports. As described earlier, Zheng et al. ${ }^{7}$ achieved detection of approximately 1000 ferucarbotran-labeled human embryonic stem cells (27 ng $n /$ cell, $27 \mathrm{ng}$ ) with SNR > 5. Our MSC detection limit was higher (4000 cells 
A

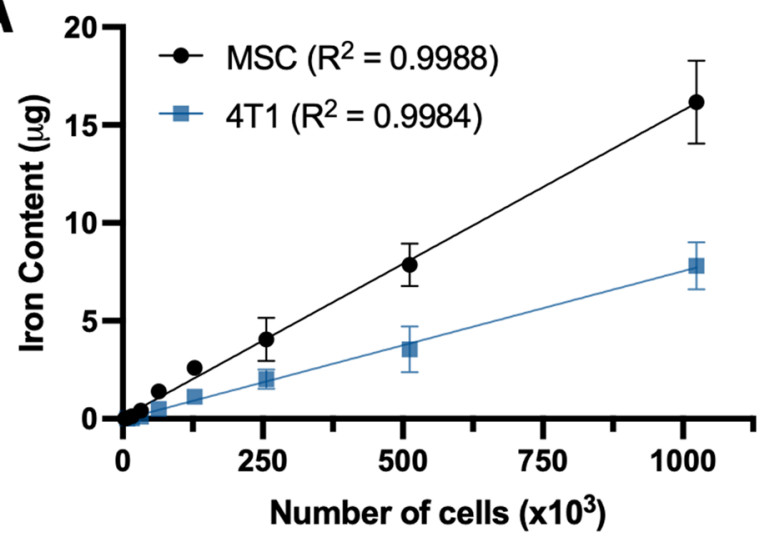

B

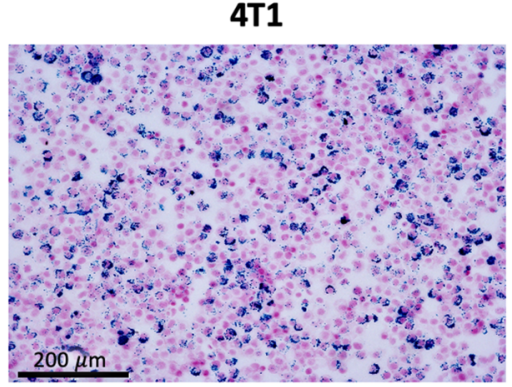

C

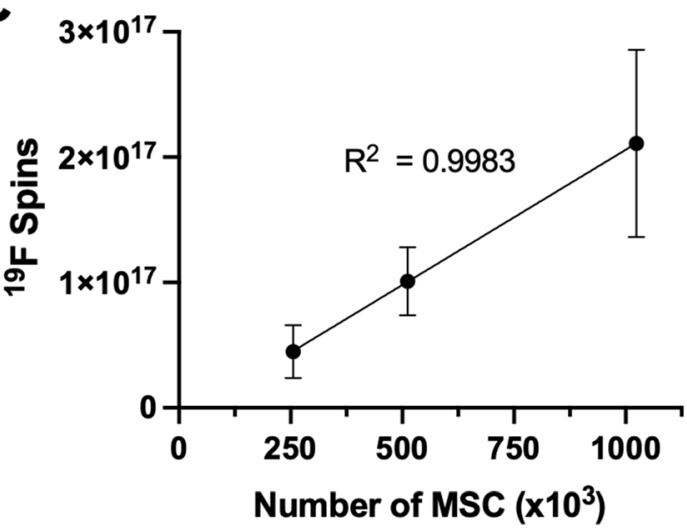

D

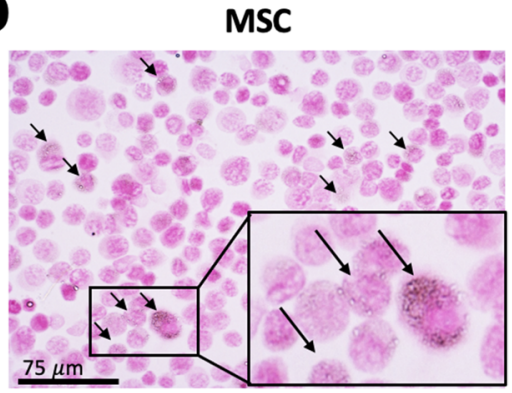

Figure 5. (A) The number of ferucarbotran-labeled MSC and 4T1 cells is strongly correlated with iron content measured by MPI $\left(\mathrm{R}^{2}>0.998\right)$. The slope of the line for MSC is higher than $4 \mathrm{~T} 1(P<.0001)$, indicating higher sensitivity and enhanced uptake of iron in MSC compared to 4T1 cells as shown with PPB stain (B). (C) A strong linear correlation exists between the number of PFPE-labeled MSC and detected ${ }^{19} \mathrm{~F}$ signal $\left(\mathrm{R}^{2}=0.9983\right)$. (D) PFPE labeling identified as nanodroplets in microscopy (black arrows).

A
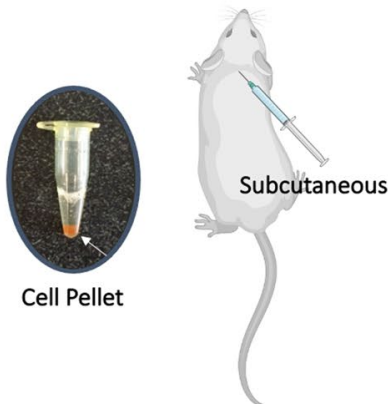

D

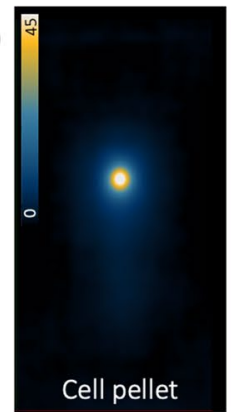

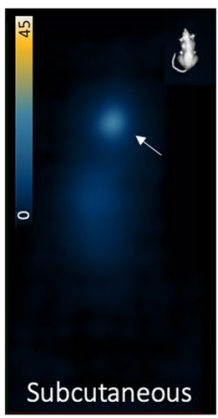
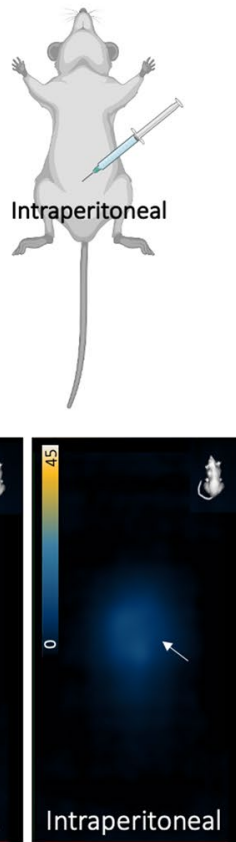

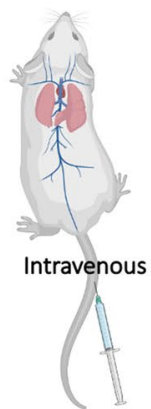

B
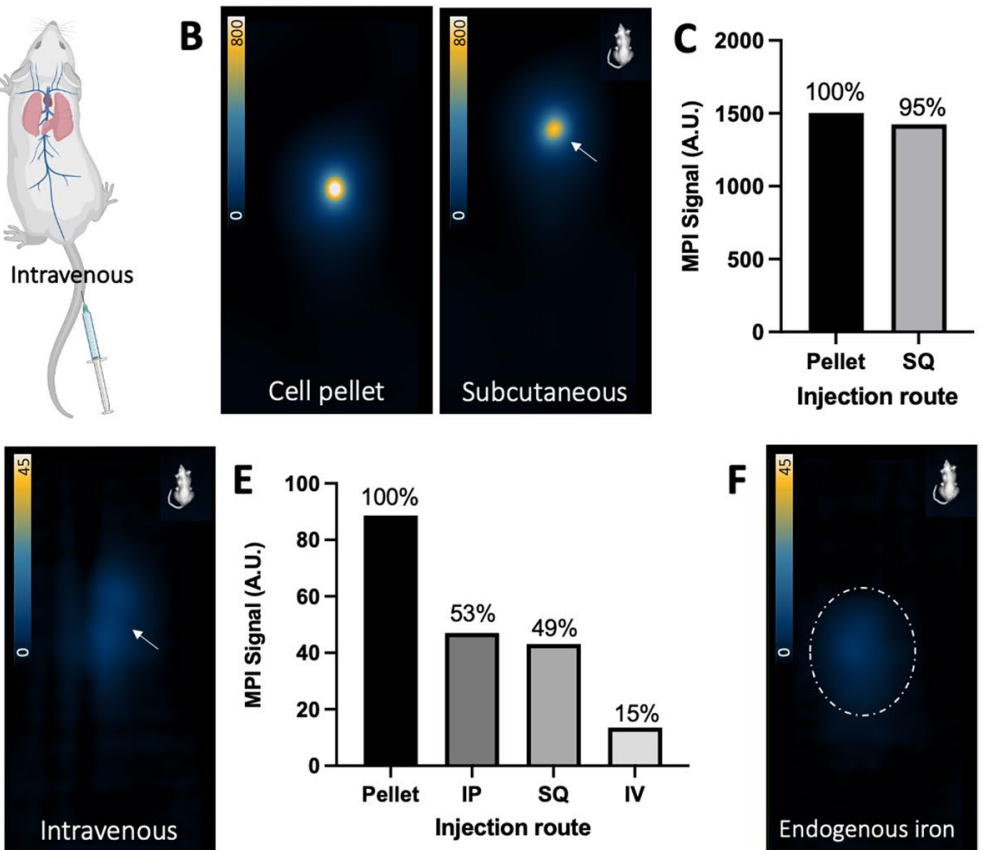

$\mathbf{F}$

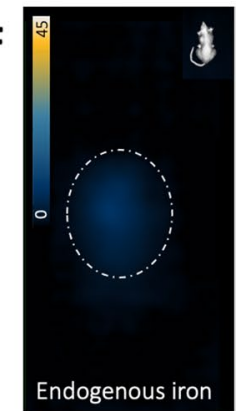

Figure 6. (A) Cartoon showing subcutaneous (SQ), intraperitoneal (IP), and intravenous (IV) injection in mice. (B) Comparison of MPI signal from 2D scans of $2 \times 10^{6}$ ferucarbotran-labeled MSC in a cell pellet to subcutaneous injection. (C) Measured MPI signal from $2 \times 10^{6} \mathrm{MSC}$ was similar in vivo and ex vivo. (D) Detection in $2 \mathrm{D}$ of $1 \times 10^{5}$ ferucarbotran-labeled MSC as a cell pellet and after subcutaneous, intraperitoneal, and intravenous injection. (E) Measured MPI signal from $1 \times 10^{5}$ cells is reduced in vivo compared to signal in the pellet. (F) Some background MPI signal exists owing to iron in mouse digestion. This signal was minimized with 12 -h fasting and accounted for by subtracting pre-injection signal from post-injection signal for each mouse. 

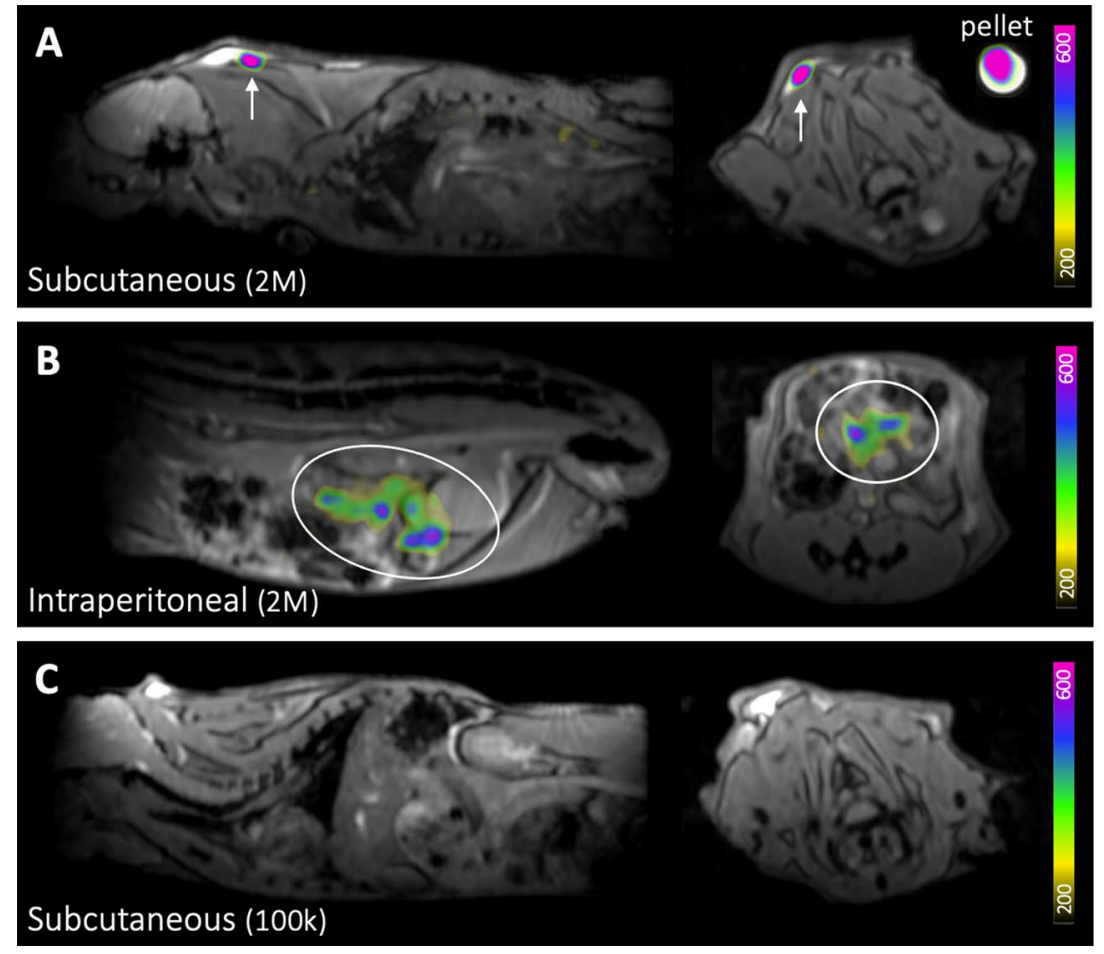

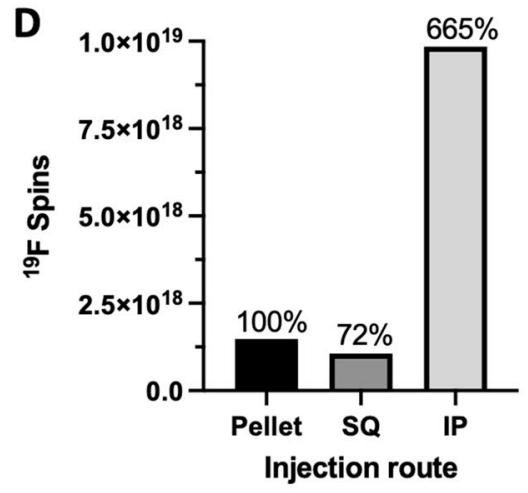

E

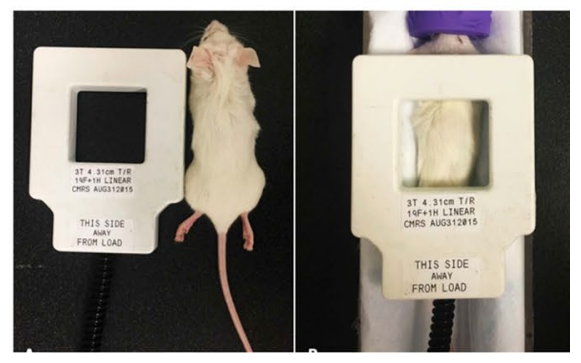

Figure 7. Detection of $2 \times 10^{6} \mathrm{PFPE}-$ labeled MSC in vivo. ${ }^{19} \mathrm{~F}$ signal is detected at the injection site following (A) subcutaneous injection (white arrows) and (B) intraperitoneal injection (white ovals). A cell pellet of the same cell number was imaged alongside the mouse for comparison (shown in A). (C) After subcutaneous administration, $1 \times 10^{5}$ cells were undetected, as this cell number is below the detection threshold for MSC. Images are sagittal (left) and axial (right). $\mathrm{M}=$ million, $\mathrm{k}=$ thousand. (D) ${ }^{19} \mathrm{~F}$ signal measured from $2 \times 10^{6}$ cells injected subcutaneous (SQ) was reduced compared to signal measured from the cell pellet, however, elevated ${ }^{19} \mathrm{~F}$ signal was measured from cells following intraperitoneal (IP) injection. (E) The dual-tuned surface coil is approximately the same size as a mouse and is placed directly over the injection site for imaging.

or $76 \mathrm{ng}$ ) and this is resulting from differences in MPI systems and acquisition. The amount of iron we detected (76 ng) is consistent with findings by Liu et al. ${ }^{19}$, where $64 \mathrm{ng}$ ferucarbotran could be detected with mean SNR of 3.6, using another MOMENTUM MPI system and the same 2D imaging parameters. With longer imaging times in 3D, we demonstrated a minimum of 1000 ferucarbotran-labeled MSC (19 ng) could be visualized with $\mathrm{SNR}>3$. To the best of our knowledge, this is the lowest report of ferucarbotran detected from labeled cells. This study was the first to measure MPI detection limits for iron-loaded cancer cells (in 3D, as few as $40004 \mathrm{~T} 1$ cells were detected, or $37 \mathrm{ng}$ iron).

Previous investigation into ${ }^{19} \mathrm{~F}$ detection limits at $3 \mathrm{~T}$ were conducted in dendritic cells $\left(3.7 \times 10^{12}{ }^{19} \mathrm{~F} / \mathrm{cell}\right)^{9}$ and macrophages $\left(7.93 \times 10^{11}{ }^{19} \mathrm{~F} / \mathrm{cell}\right)^{11}$, which have greater uptake of PFPE than what we measured in MSC $\left(3.52 \times 10^{11}{ }^{19} \mathrm{~F} / \mathrm{cell}\right)$. Ahrens et al. established an in vitro ${ }^{19} \mathrm{~F}$ MRI detection limit of $1.0 \times 10^{5}$ dendritic cells/voxel on a $3 \mathrm{~T}$ clinical scanner using a $2.5^{\star} \mathrm{SD}_{\text {noise }}$ threshold ${ }^{9}$. Similarly, we achieved detection of $1.30 \times 10^{5} \mathrm{MSC} /$ voxel $(1.5 \mathrm{~min} /$ pellet $)$ and $8.55 \times 10^{4} \mathrm{MSC} /$ voxel in longer scans $(4.5 \mathrm{~min} /$ pellet $)$ using a $5^{\star} \mathrm{SD}_{\text {noise }}$ threshold. In our previous work at $3 \mathrm{~T}$, as few as 25,000 murine macrophages were detected $\left(2.27 \times 10^{4}\right.$ cells/voxel $)$ with longer imaging time ${ }^{11}$.

Cell labeling is fundamental in determining cellular sensitivity for both MPI and ${ }^{19} \mathrm{~F}$ MRI. We previously discussed factors that impact labeling efficiency with SPIONs ${ }^{20}$. In this study, we observed enhanced MPI detectability of MSCs compared to breast cancer cells, owing to increased endocytosis of SPION. Likewise, 4T1 cells did not label with PFPE sufficiently for ${ }^{19} \mathrm{~F}$ MRI detection. Increased uptake of SPION/PFPE is expected in phagocytic cells and cells which have a larger cytoplasmic volume ${ }^{21}$, such as macrophages and dendritic cells. Although MSC is considered a non-phagocytic cell type ${ }^{22}$, enhanced labeling compared to breast cancer cells has been observed with SPIONs ${ }^{15}$ and PFPE ${ }^{10}$. The cell labeling protocols used in this study use commonly used concentrations of ferucarbotran and PFPE for cell labeling and have been well established. We, and other groups, have not observed compromises in cell viability or function at these labeling concentrations, even in delicate cell types ${ }^{12,13,23} 2^{27}$. In this study, we use transfection agents to facilitate uptake of ferucarbotran. It is expected that SPION surface modifications will be improve labeling efficiency without transfection agents ${ }^{8,28}$. Further improvements to PFPE nanoemulsions will enhance ${ }^{19} \mathrm{~F}$ cellular sensitivity, such as incorporation of paramagnetic agents ${ }^{29,30}$, or the addition of surface modifications to enhance the uptake of PFPE nanoemulsions ${ }^{31}$.

We recognize it is impossible to directly compare cell detection with MPI and ${ }^{19} \mathrm{~F}$ MRI due to their inherent differences, including structural configurations and imaging parameters. For this study, we attempted to optimize unique aspects of each modality in favor of sensitivity. MPI of cells was conducted using weak gradients 
( $3 \mathrm{~T} / \mathrm{m}$ ) to increase the size of the FFR and enhance sensitivity. For FFL (line) MPI, the use of weak gradients $(3 \mathrm{~T} / \mathrm{m})$ compared to stronger gradients $($ e.g. $6 \mathrm{~T} / \mathrm{m})$ expands the volume of FFR. This leads to enhancement in sensitivity, at the cost of reduced resolution. It is also expected that signal averaging would improve sensitivity, however this has not been studied for MPI. In 2D, a significant reduction in background noise was measured with 8 averages compared to 1 average, however, this did not improve cell detection with MPI, as we defined it. 3D imaging using 35 projections did offer improvement in sensitivity for both ferucarbotran-labeled MSC (detection of 2000 cells) and breast cancer cells (4000 cells). Lastly, optimization of excitation amplitudes may lead to improved cell sensitivity; in this study we used $22 \mathrm{mT}$ (X-channel) and $26 \mathrm{mT}$ (Z-channel) by default.

${ }^{19} \mathrm{~F}$ MRI of PFPE-labeled cells was conducted at a clinical field strength $(3 \mathrm{~T})$. The implementation of the surface coil and optimized 3D bSSFP sequence is crucial to enable ${ }^{19} \mathrm{~F}$ cell tracking at $3 \mathrm{~T}$. The theoretical optimal flip angle for ${ }^{19} \mathrm{~F}$ at $3 \mathrm{~T}$ is $72^{\circ}$ and our investigation showed highest SNR was produced for flip angles between $60-80^{\circ}$. However, transmit/receive surface coils provide non-uniform sensitivity, due to spatial variations in applied energy and flip angle ${ }^{32,33}$. For this reason, cell pellets were imaged directly in the center of the coil to maximize sensitivity. Likewise, the surface coil was placed directly above the region of interest for in vivo ${ }^{19} \mathrm{~F}$ imaging. High signal averaging was used for ${ }^{19} \mathrm{~F}$ image acquisition (115) to improve SNR. Longer imaging times with 345 signal averages enabled detection of 3 additional pellets of $256 \times 10^{3}$ cells and 3 of 9 pellets of $128 \times 10^{3}$ PFPE-labeled MSC.

After assessing in vitro cell detection limits of MPI and ${ }^{19} \mathrm{~F}$ MRI, a preliminary assessment of in vivo detection factors was conducted. It has previously been shown that there is no attenuation of MPI signal from biological tissue $^{34,35}$. In agreement, following subcutaneous injection of $2 \times 10^{6} \mathrm{MSC}$, we measured only a small reduction in cell detection with MPI (5\%). However, for a lower cell number $\left(1 \times 10^{5}\right)$, there was reduction of signal measured in vivo compared to the pellet (by $47-85 \%$, depending on injection route). Here we recognize that the dispersion of cells from the injection site reduces the cell density per voxel, leading some cells to fall below the intravoxel detection limit. MPI detection of MSC was most reduced after intravenous injection (85\% reduction). It is expected that cells administered intravenously would be most disperse as they circulate through the venous circulation before accumulating in the lung capillaries (shown in Fig. 6A). Similarly, previous work by Wang et al. $(2020)^{8}$ showed that $1 \times 10^{5}$ ferucarbotran-labeled stem cells could be detected with MPI in vivo following subcutaneous injection but not following intravenous injection. In our study, we could achieve detection of $1 \times 10^{5}$ cells after intravenous injection, which can be attributed to the choice of gradient strength $(3.0 \mathrm{~T} / \mathrm{m} \mathrm{vs} .5 .7 \mathrm{~T} / \mathrm{m})$.

Likewise for ${ }^{19} \mathrm{~F}$ MRI, dispersion of PFPE-labeled cells $\left(1 \times 10^{6}\right)$ in patients was previously reported to limit the detectability of these cells following administration ${ }^{9}$. In our study, ${ }^{19} \mathrm{~F}$ signal detected from a cell pellet of $2 \times 10^{6}$ PFPE-labeled MSC was higher than ${ }^{19} \mathrm{~F}$ signal from the same number of cells injected subcutaneously. Conversely, ${ }^{19} \mathrm{~F}$ signal measured from cells injected to the intraperitoneal space was overestimated. This result could be explained by the large quantification region, as ${ }^{19} \mathrm{~F}$ density per imaging voxel was $3.79 \times 10^{16}{ }^{19} \mathrm{~F} / \mathrm{mm}^{3}$ for cells in a pellet, compared to $2.03 \times 10^{16}{ }^{19} \mathrm{~F} / \mathrm{mm}^{3}$ for cells in vivo.

For both MPI and MRI, there are other important considerations which reduce detectability of cells in vivo. For MPI, this includes increased background signal associated with mouse digestion ${ }^{36}$. While we accounted for background signal in the mouse using signal subtraction, this technique is not permissible for longitudinal cell tracking studies. Background signal is variable across mice and day-to-day. In our experience, this can be reduced by mouse fasting, however, the amount of signal is unpredictable. Ultimately this background signal may obscure detection of cells, especially in low cell numbers ${ }^{37}$, as it is challenging (at this time, impossible) to distinguish the signal associated with cells from background. Second, there is some evidence that Brownian relaxation of SPION in different tissue environments may be altered, leading to reduced MPI sensitivity ${ }^{38}-{ }^{40}$. Brownian motion refers to the physical rotation of SPIONs; this motion is reduced in tissues with increased stiffness (e.g. muscle) which leads to increased Brownian relaxation times (thus, lower sensitivity and resolution). Ongoing work aims to determine whether this plays a role in the detection of SPION-labeled cells. Another consideration affecting ${ }^{19} \mathrm{~F}$ detection of PFPE-cells in vivo is the coil filling factor. The volume of a mouse is much larger than the volume of a cell pellet, thus SNR for detection of cells in vivo is expected to be reduced due to increased image noise. Lastly, mouse breathing motion can lead to blurring of signal which will reduce the maximum signal intensity associated with cells and could potentially render cells undetected by MRI and MPI.

\section{Conclusion}

MPI has the potential to be more sensitive than ${ }^{19} \mathrm{~F}$ MRI for cell tracking. In this study, commonly used cell labeling agents, ferucarbotran and perfluoropolyether nanoemulsions, were used to label MSC and 4T1 cells to assess cellular sensitivity of MPI and ${ }^{19} \mathrm{~F}$ MRI, respectively. Fewer MSC (4000 cells, 76 ng iron) were detected with MPI than ${ }^{19} \mathrm{~F}$ MRI $\left(256,000\right.$ cells, $9.01 \times 10^{16}{ }^{19} \mathrm{~F}$ atoms $)$, using the same scan time. Furthermore, reduced ferucarbotran labeling was observed in $4 \mathrm{~T} 1$ breast cancer cells compared to MSC, leading to a detection limit of 8000 breast cancer cells ( $74 \mathrm{ng}$ iron). With longer imaging times, as few as $2000 \mathrm{MSC}$ ( $38 \mathrm{ng}$ ferucarbotran) and 4000 breast cancer cells (37 ng ferucarbotran) were detected with MPI and 128,000 MSC $\left(4.51 \times 10^{16}{ }^{19} \mathrm{~F}\right.$ atoms) were detected with ${ }^{19} \mathrm{~F}$ MRI with $\mathrm{SNR}>5$. Determination of these detection thresholds in vitro is useful to anticipate the minimum number of cells that are required for detection in vivo. However, we demonstrated that there are several factors in vivo which led to reduced detectability of cells, particularly the effect of cell dispersion which reduces cell density per imaging voxel. There is no doubt that cellular sensitivity for these modalities will continue to improve with further developments. It is essential to understand and improve cellular sensitivity to advance imaging of cellular therapeutics. 
Received: 11 September 2021; Accepted: 18 October 2021

Published online: 12 November 2021

\section{References}

1. Bulte, J. W. M. \& Daldrup-Link, H. E. Clinical tracking of cell transfer and cell transplantation: trials and tribulations. Radiology 2, 1069 (2018)

2. "Clinicaltrials.gov."

3. Daldrup-Link, H. E. et al. Detection of stem cell transplant rejection with ferumoxytol MR imaging: correlation of MR imaging findings with those at intravital microscopy. Radiology 284(2), 495-507 (2017).

4. Tay, Z. W., Hensley, D. W., Vreeland, E. C., Zheng, B. \& Conolly, S. M. The relaxation wall: experimental limits to improving MPI spatial resolution by increasing nanoparticle core size. Biomed. Phys. End Express 3(3), 1-21 (2017).

5. Bauer, L. M., Situ, S. F., Griswold, M. A. \& Samia, A. C. S. Magnetic particle imaging tracers: state-of-the-art and future directions. J. Phys. Chem. Lett. 6(13), 2509-2517 (2015).

6. Eberbeck, D., Wiekhorst, F., Wagner, S. \& Trahms, L. How the size distribution of magnetic nanoparticles determines their magnetic particle imaging performance. Appl. Phys. Lett. 98(18), 1-4 (2011).

7. Zheng, B. et al. Magnetic particle imaging tracks the long-term fate of in vivo neural cell implants with high image contrast. Sci. Rep. 5(March), 1-9 (2015).

8. Wang, Q. et al. Artificially engineered cubic iron oxide nanoparticle as a high-performance magnetic particle imaging tracer for stem cell tracking. ACS Nano 14(2), 2053-2062 (2020).

9. Ahrens, E. T., Helfer, B. M., O’Hanlon, C. F. \& Schirda, C. Clinical cell therapy imaging using a perfluorocarbon tracer and fluorine-19 MRI. Magn. Reson. Med. 72(6), 1696-1701 (2014).

10. Srinivas, M., Boehm-Sturm, P., Figdor, C. G., de Vries, I. J. \& Hoehn, M. Labeling cells for in vivo tracking using 19F MRI. Biomaterials 33(34), 8830-8840 (2012).

11. Makela, A. V. \& Foster, P. J. Preclinical 19 F MRI cell tracking at 3 Tesla. Magn. Reson. Mater. Phys Biol. Med. 32(1), 123-132 (2019).

12. Zhang, X. et al. Cellular magnetic resonance imaging of monocyte-derived dendritic cell migration from healthy donors and cancer patients as assessed in a scid mouse model. Cytotherapy 13(10), 1234-1248 (2011).

13. Fink, C. et al. 19F-perfluorocarbon-labeled human peripheral blood mononuclear cells can be detected in vivo using clinical MRI parameters in a therapeutic cell setting. Sci. Rep. 8(1), 1-13 (2018).

14. Thu, M. S. et al. Self-assembling nanocomplexes by combining ferumoxytol, heparin and protamine for cell tracking by MRI HHS public access author manuscript. Nat. Med. 18(3), 463-467 (2012).

15. Mcfadden, C., Mallett, C. L. \& Foster, P. J. Labeling of multiple cell lines using a new iron oxide agent for cell tracking by MRI. Contrast Media Mol. Imaging 2, 19 (2011).

16. Scheffler, K. \& Lehnhardt, S. Principles and applications of balanced SSFP techniques. Eur. Radiol. 13(11), 2409-2418 (2003),

17. Rose, A. The sensitivity performance of the human eye on an absolute scale. J. Opt. Soc. Am. 38(2), 196-208 (1948).

18. Bouchlaka, M. N. et al. 19F-MRI for monitoring human NK cells in vivo. Oncoimmunology 5(5), 1-12 (2016).

19. Liu, S. et al. Long circulating tracer tailored for magnetic particle imaging. Nanotheranostics 5(3), 348-361 (2021).

20. Sehl, O. C., Gevaert, J. J., Melo, K. P., Knier, N. N. \& Foster, P. J. A perspective on cell tracking with magnetic particle imaging. Tomography 6(4), 49 (2020).

21. Ahrens, E. T. \& Bulte, J. W. M. Tracking immune cells in vivo using magnetic resonance imaging. Nat. Rev. Immunol. 13(10), 16900 (2013).

22. Moonshi, S. S. et al. A unique 19F MRI agent for the tracking of non phagocytic cells: In vivo. Nanoscale 10(17), 8226-8239 (2018).

23. Fink, C. et al. Quantification and characterization of granulocyte macrophage colony-stimulating factor activated human peripheral blood mononuclear cells by fluorine-19 cellular MRI in an immunocompromised mouse model. Diagn. Interv. Imaging 2, 10639 (2020).

24. Fink, C. et al. Fluorine-19 cellular MRI detection of In Vivo dendritic cell migration and subsequent induction of tumor antigenspecific immunotherapeutic response. Mol. Imaging Biol. 19, 1023 (2019).

25. Chickera de, S. et al. Cellular MRI as a suitable, sensitive non-invasive modality for correlating in vivo migratory efficiencies of different dendritic cell populations with subsequent immunological outcomes. Int. Immunol. 24(1), 29-41 (2012).

26. Rivera-rodriguez, A., Hoang-minh, L. B., Chiu-lam, A. \& Sarna, N. Tracking adoptive T cell therapy using magnetic particle imaging. Sci. Rep. 2, 1-17 (2020).

27. Parkins, K. M., Melo, K. P., Chen, Y., Ronald, J. A. \& Foster, P. J. Visualizing tumour self-homing with magnetic particle imaging. Nanoscale 13(12), 6016-6023 (2021).

28. Lu, C. et al. Engineering of magnetic nanoparticles as magnetic particle imaging tracers. Chem. Soc. Rev. 50(14), 8102-8146 (2021).

29. Jahromi, A. H. et al. Fluorous-soluble metal chelate for sensitive fluorine-19 magnetic resonance imaging nanoemulsion probes amin. ACS Nano 13(1), 143-151 (2019).

30. Rho, J. et al. Paramagnetic fluorinated nanoemulsions for in vivo F-19 MRI. Mol. Imaging Biol. 22(3), 665-674 (2020).

31. Hingorani, D. V. et al. Cell penetrating peptide functionalized perfluorocarbon nanoemulsions for targeted cell labeling and enhanced fluorine-19 MRI detection. Magn. Reson. Med. 31, 1-14 (2019).

32. Vernikouskaya, I., Pochert, A., Lindén, M. \& Rasche, V. Quantitative 19 F MRI of perfluoro-15-crown-5-ether using uniformity correction of the spin excitation and signal reception. Magn. Reson. Mater. Phys. Biol. Med. 32(1), 25-36 (2019).

33. Mihara, H., Iriguchi, N. \& Ueno, S. A method of RF inhomogeneity correction in MR imaging. Magn. Reson. Mater. Phys. Biol. Med. 7, 115-120 (1998).

34. Zheng, B. et al. Quantitative magnetic particle imaging monitors the transplantation, biodistribution, and clearance of stem cells in vivo. Theranostics 6(3), 291-301 (2016).

35. Saritas, E. U. et al. Magnetic particle imaging (MPI) for NMR and MRI researchers. J. Magn. Reson. 229, 116-126 (2013).

36. Sehl, O. C., Makela, A. V., Hamilton, A. M. \& Foster, P. J. Trimodal cell tracking in vivo: combining iron- and fluorine-based magnetic resonance imaging with magnetic particle imaging to monitor the delivery of mesenchymal stem cells and the ensuing inflammation. Tomogr. Ann Arbor Mich. 5(4), 1029 (2019).

37. Boberg, M. et al. Simultaneous imaging of widely differing particle concentrations in MPI: problem statement and algorithmic proposal for improvement. Phys. Med. Biol. 2, 963 (2021).

38. Arami, H., Ferguson, R. M., Khandhar, A. P. \& Krishnan, K. M. Size-dependent ferrohydrodynamic relaxometry of magnetic particle imaging tracers in different environments. Med. Phys. 40(7), 1-14 (2013).

39. Utkur, M., Muslu, Y. \& Saritas, E. U. Relaxation-based color magnetic particle imaging for viscosity mapping. Appl. Phys. Lett. 115(15), 10533 (2019).

40. Draack, S. et al. Multiparametric magnetic particle spectroscopy of CoFe2O4 nanoparticles in viscous media. J. Phys. Chem. C 123(11), 6787-6801 (2019).

\section{Acknowledgements}

We would like to acknowledge funding from the Natural Science and Engineering Council of Canada. 


\section{Author contributions}

O.C.S and P.J.F. designed the experiments. O.C.S. conducted the experiments, analysed the data, and wrote the main manuscript. P.J.F. reviewed the manuscript.

\section{Competing interests}

The authors declare no competing interests.

\section{Additional information}

Supplementary Information The online version contains supplementary material available at https://doi.org/ 10.1038/s41598-021-01642-3.

Correspondence and requests for materials should be addressed to O.C.S.

Reprints and permissions information is available at www.nature.com/reprints.

Publisher's note Springer Nature remains neutral with regard to jurisdictional claims in published maps and institutional affiliations.

(c) (i) Open Access This article is licensed under a Creative Commons Attribution 4.0 International License, which permits use, sharing, adaptation, distribution and reproduction in any medium or format, as long as you give appropriate credit to the original author(s) and the source, provide a link to the Creative Commons licence, and indicate if changes were made. The images or other third party material in this article are included in the article's Creative Commons licence, unless indicated otherwise in a credit line to the material. If material is not included in the article's Creative Commons licence and your intended use is not permitted by statutory regulation or exceeds the permitted use, you will need to obtain permission directly from the copyright holder. To view a copy of this licence, visit http://creativecommons.org/licenses/by/4.0/.

(C) The Author(s) 2021 